\title{
THOMAS MOORE IN THE CREATIVE PERCEPTION OF ALEXANDER PUSHKIN
}

\author{
Dmitry N. Zhatkin ${ }^{1,}$ Tatiana A. Yashina ${ }^{1}$ \\ ${ }^{1}$ Department of Translation and Methods of Translation, Penza State Technological University, Penza, \\ Russian Federation
}

Correspondence: Zhatkin Dmitry Nikolaevich, Department of Translation and Methods of Translation, Penza State Technological University, Baidukov Thoroughfare / Gagarin Street, 1a / 11, Penza, Russian Federation

\begin{abstract}
The article is devoted to revealing T.Moore's traditions in the works of Alexander Pushkin. In the article the reasons of Pushkin's negative attitude toward the works of Thomas Moore are being analyzed, as well as Pushkin's assessment of the role of T. Moore in the development of world literature, and the images of T. Moore's poetry, borrowed by Pushkin. The views of literary critics on the problem of the creative interrelations of the two poets are given. The article is methodologically based on the foundations of historical poetics, the theses of M.M.Bakhtin's theory of dialogues and «another's word», the works of the representatives of the Leningrad school of comparative historical literature, created by M.P. Alekseev. When analyzing, the socio-cultural, comparative-historical, cultural-historical and comparative-typological methods of research have been used. Despite the positive reaction of the Russian press to Thomas Moore in the early XIX century, a completely different position was taken by Pushkin, who reasonably explained his negative perception of Moore's works, opposing him to Byron. Many researchers have tried to find any convergence points in the works of Moore and Pushkin, pointing to the allusions from T. Moore's «Lalla Rookh, an oriental romance» in the works of Pushkin. On the other hand, after the publication of the book «Letters and Journals of Lord Byron with Notices of His Life», prepared by Moore, in London in 1830, many lovers of English literature in Russia began perceiving Thomas Moore not so much as the original poet, but as Byron's biographer. As a witness to the first stage of the development of Byronism in Russia, the appearance of the first translations of the great English poet, A.I. Turgenev, in a note compiled at the request of Thomas Moore, singled out two poems among Pushkin's creative works that were perceived as «Byronic», - «To the Sea» (1824) and «Napoleon» (1821), which allowed Thomas Moore to get some idea of Pushkin's Byronism. Negatively speaking about Moore and expressing his rejection of his «Lalla Rookh, an oriental romance»», Pushkin in no way belittled the role of the Irish poet in the development of world literature, often calling his name along with the names of recognized foreign classics and trying not to lose sight of Moore's new works, carefully reading them and including even the rarest ones in his library.
\end{abstract}

Keywords: Russian-English literary and historical - cultural ties, poetry, romanticism, A.S.Pushkin, tradition, reception, artistic translation, intercultural communication.

\section{INTRODUCTION}

Despite the positive reaction of the Russian press to the works of Thomas Moore in the early XIX century, especially after the appearance of the second part of «Lalla Rookh» («Paradise and the Peri»), translated by V.A. Zhukovsky («Peri and the Angel»), in the pages of «Son of Fatherland» in 1821, we can see the negative attitude of Pushkin to Moore and his works, though his voice sounded lonely. Pushkin wrote to P.A. Vyazemsky on January 2, 1822: «Zhukovsky is driving me mad - what does he like about this Moore? A stiff imitator of an ugly Oriental imagination? The whole «Lalla Rookh» is not worth the ten lines of "Tristram Shandy"» [1, v. 9, p. 36]. There are some other judgments, preserved in the epistolary of the great Russian poet, that confirm Pushkin's negative attitude towards the «ugly Oriental imagination», that Moore vainly mimicked. In particular, on June 27,1822 , in a letter to N.I.Gnedich, Pushkin spoke of the vexation he experienced, when Zhukovsky's «ugly stories of Moore» appeared. Recognizing that «English literature is having an impact on the Russian one», the great Russian poet, at the same time, made a clear dividing line between the works of Byron and Moore: «I am looking forward to the "The Prisoner of Chillon"; it's not match of "Peri" and is worthy of such an interpreter as the singer of Thunderbolt and the Old Woman» [1, v. 9, p. 42]. In a letter to P.A. Vyazemsky, dated late March - early April 1825, Pushkin gives a reasoned 
explanation of the inner essence of his negative perception of Moore's artistic creativity, again opposing him to Byron: «... Do you know why I do not like Moore? - because he is too oriental. He imitates childishly and ugly - the childishness and ugliness of Saadi, Hafiz and Mohammed - being in the ecstasy of eastern luxury, the European must preserve the taste and look of the European. That why Byron is so charming in «The Giaour», in «The Bride of Abydos» and so on» [1, v. 9, p. 142]. Having remained true to his opinion over time, Pushkin again negatively spoke about the «Lalla Rookh» of Moore in his letter to P.A.Vyazemsky, dd. late November 1825: «The act of Moore (Moore's burning of Byron's notes - D.Z., T.Ya.) is better than his «Lalla Rookh» (in poetic terms)» [1, v. 9, p. 215]. With his negative perception of the «eastern luxury» of Moore, Pushkin in many respects outstripped the time and was not understood by his contemporaries for long; only in the 1830s the polemical judgments about the «eastern imagination» of Moore began to appear in domestic journalism and literary criticism.

\section{MATERIALS AND METHODS}

The materials for the analysis are as follows: English romantic poems and their translations into Russian, their literary criticism, and Russian poems, containing reminiscences from the works of their English predecessors. The methods of historical poetics are used, which makes it possible to comprehend the functions of certain typical motifs and images, to consider features of national identity in works, to understand the specifics of the lyrical character, and so on. According to the principle of historicism, certain facts and circumstances are considered in connection with others, taking into account the historical, literary and cultural experience. In accordance with the subject of study, sociocultural, comparative-historical, cultural-historical and comparative-typological of research methods are naturally used.

\section{RESULTS}

Pushkin based his views about «Lalla Rookh» and Moore's works on V.A.Zhukovsky's translation of «Peri and the Angel» and a prosaic fragment of «Lalla Rookh», translated by N.A.Bestuzhev, published in 1821 in the «Competitor of Education and Beneficence» (Part 16), and then as a separate edition. In Pushkin's library there was a complete prosaic translation of «Lalla Rookh» into French [2, p. 217], published by Amedée Pichot in 1820 [3; 4, p. 109, 132], from which one could conclude that the Russian poet was familiar with all parts of Moore's romance and could make his judgments based on a holistic perception of the entire text.

Constantly monitoring the appearance of new and new translations from T.Moore in Russian periodicals, including those carried out by P.Vyazemsky, I.Kozlov, Pushkin not only kept his well-known attitude to the works of the author of «Lalla Rookh», but also, in many respects, transferred his antipathy to those modern Russian poets, who aspired to follow the tradition of Moore, imitating the eastern motives of his poem. Here one can, in particular, name A.I.Podolinsky, who published in 1827 his first poem («story in verse») «Div and Peri», which made the representatives of the literary environment hoping a new original talent to emerge. N.A. Polevoy and his adherents - the opponent of the Pushkin circle - began to thank Podolinsky «on behalf of humanity» on pages of Russian periodicals, which from outside was difficult to perceive without irony. Pushkin did not accept Podolinsky's poem for the same reason, that he could not accept the translation of Zhukovsky's «Peri and the Angel»: in these poems, an oriental coloring was shown in an almost pretentious manner, in an unacceptable for the great poet form.

The imperative tone and lack of certainty in N.A.Polevoy's laudatory statements bewildered the representatives of Pushkin circle; his one-sided self-confident reasoning adversely affected young Podolinsky, who became even more careless in his lingual euphony, which was manifested in his second poem «Borsky», negatively met by Russian critics [5, p. 226]. At A.A. Delvig's party on February 24, 1829, where Podolinsky was among the guests, «a boy swelled up by panegyrists and Polevoy», Pushkin expressed an interesting idea, transferred the next day by S.P.Shevyrev in his letter to M.P.Pogodin: «Polevoy thanked Podolinsky for «Div and Peri» on behalf of humanity, now it's not bad to scold him for «Borsky» on behalf of the Universe» [6, p. 703].Thus, we can talk about the negative attitude of Pushkin not only to Moore, but also to A.I.Podolinsky as his younger Russian follower.

In his article on Byron's «Manfred», translated by M.P.Vronchenko, the above mentioned S.P.Shevyrev attributed Moore and Pushkin to different groups of writers. The first group, who took material for creativity from the outside world, included, in addition to Pushkin, also J.W.Goethe, W.Scott, W.Irving, and F.Cooper. 
The second group of authors, who appealed to soul and inner world of a person, included F.Schiller, G.G.Byron, T.Moore, V.A.Zhukovsky, and A.Mickiewicz. In the opinion of S.P.Shevyrev, in some romantic poems, first of all in the «Prisoner of the Caucasus» and «The Fountain of Bakchisarai», «our Pushkin passes into the second row, but in these works he is the imitator rather than the original one» [7, p. 57-58]. At the same time, one cannot but mention the controversial attempts of the contemporaries and researchers of Pushkin's life and creativity to bring together his own works and those of Moore's. These attempts originate from the well-known judgment of K.A. Polevoy, who wrote in 1834 that Pushkin was «the kind of our Byron with an admixture of Moore» [6, p. 750]. After the publication of the book «Materials for the Biography of Pushkin» by P.V.Annenkov (St. Petersburg, 1855), numerous responses appeared (N.G.Chernyshevsky, A.V.Druzhinin, N.A. Dobrolyubov, A.A.Grigoriev and etc.), among which was the review of V.P. Gaevsky, who expressed in the «Otechestvennye zapiski» [«The Notes of the Fatherland»] an opinion about Moore's tradition found in Pushkin's poem «Echo» (1831): «The main idea of it belongs to Pushkin himself, but some details and even the size of the poem expose the author of "Irish melodies"» [8, p. 61]. The remark prompted publishers giving the subtitle «From Thomas Moore» to the poem «Echo» (in the late XIX - early XX century), until N.V.Yakovlev established a roll-call between Pushkin's «Echo» and the earlier poem «Coastal echo» by B. Cornwall [9, p. 20-25]. In his later work «From Findings about Literary Sources in Pushkin's Works», N.V.Yakovlev tried to bring together Pushkin's «Egyptian Nights» and «New Thoughts on Old subjects» (1828) by S.-T. Coleridge, where some improviser attempted to briefly convey the essence of one of the «Irish melodies» by T.Moore - «Believe me if all those endearing young charms...» [10, p. 140-144]; however, this attempt to draw an indirect parallel between Pushkin and Moore should be recognized as shaky and lacking of substantive evidence.

These attempts to find the convergence between the works of Moore and Pushkin were based on certain analysis of the scope of reading of both the greatest Russian poet and his contemporaries. For example, it is known that Moore's works were in the library of the village of Trigorskoe [11, p. 19-20], and Anna Nikolaevna Wolf was a great admirer of the English poet. This circumstance, confirmed by Pushkin in a letter to Alexei - Anna Nikolaevna's brother - on October 16, 1829 («In Malinniki I only found Anna Nikolaevna with a gumboil and with Moore» [1, v. 9, p. 295]), suggested, that, when living in Mikhailovskoye, Pushkin could take Moore's books from the library of his acquaintance in Trigorskoe [12, p. 41-42]. There are numerous extracts from the «Irish melodies» both in English and in Russian translations of M.P.Vronschenko and P.A.Vyazemsky in the Album of A.N.Wolf, stored in the Institute of Russian Literature (IRLI) [13].

In Pushkin's own library, by words of B.L.Modzalevsky, one could find among others very rare, almost unknown works of Moore, for example, there were «Epicurean», «Biography of Sheridan», «Life and Death of Lord Edward Fitzgerald», «Memoirs of Captain Rock», «Travels of an Irish gentleman in Search of a Religion» in original language (it was the part of the Paris series of «Baudry's Collection of Ancient and Modern British Authors», published in 1835 [2, p. 153]. The last of the named works, translated into French in 1833, with the litter «Pushkin» on the cover, scribed by his hand, was also available in the library [14, p. 606]. There was the Parisian edition of «The Poetical Works of Thomas Moore in one volume» dd. 1829 [2, p. 294], which included, beside the well-known «Irish melodies» and ballads, also the political-satirical works of Moore, that were missed by the Russian censors, who did not realize the depth of the stinging hints of the English poet. This book, containing the full texts of such poignant works as «Fudge Family in Paris», 1818 and «Fable for the Holy Alliance», 1823) [15, p. 136-156, 180-186], became widespread in the Russian literary environment, was available in the home collections of many contemporaries of Pushkin.

It is interesting to see, what names stand close to the name of Thomas Moore in the creative consciousness of Pushkin. In an unfinished essay «On A. Bestuzhev's article "A Look at Russian Literature in 1824 and Early 1825"» (1825), Pushkin opposed Bestuzhev's view of the first period of literature as «the century of strong feelings and brilliant creations», followed by a decline, seeing no special regularity in it. «Rom <antic> lit<erature> began with triolets $\langle\ldots$. . . After the Cavalier Marini there appeared Alfieri, Monti i Foscolo, and after Pope and Addison - Byron, Moore and Souve» [1, v. 6, p. 261]. Later Pushkin preferred to express his thoughts not in the form of an article, left unfinished, but in a letter to A.A.Bestuzhev, dd. late May - early June 1825: «The Englishmen Milton and Shakespeare were prior to Addison and Pope, after them appeared 
Southay, Walter Scott, Moor and Byron, so it is difficult to draw any conclusion or rule from this» [1, v. 9, p. $158]$.

In his drafts of the preface to the first chapter of «Eugene Onegin» Pushkin mentioned Moore next to Byron [16, p. 528], and in the article «On Byron and on important subjects» (1835) he relied on the opinion of Moore as the authoritative biographer of Byron: «Moore is right to observe that the character of $\mathrm{B}<\mathrm{yron}>$ vividly reflected the virtues and vices of his ancestors: on the one hand, courageous enterprise, generosity, nobility of feelings, on the other, unbridled passions, oddities and defiant contempt to the common opinion» [1, v. 6, p. 51]. In his earlier article, «Reviews on the Almanac "Dennitsa" 1830», published in Literaturnaya gazeta (Literaturnaya Gazeta, 1830 - No. 8) without a signature, Pushkin quoted I.V.Kireevsky, that there were «six foreign poets who shared the love of our writers, they are: Goethe, Schiller, Shakespeare, Byron, Moore and Mickiewicz» [1, v. 6, p. 51]. Pushkin mentioned Moore in a completely different series of the famous names in his poem «To ***» («You are a Lady, no doubt...», 1826): «There is another God, of earthly circle - / The Beauty obeys him, / God of Parny, Tibull, Moore, / Tormented by him, I am comforted by him» [1, v. 2, p. 161].

\section{DISCUSSION}

Negatively perceiving Thomas Moore together with his famous romantic poem «Lalla Rookh», criticizing the unskillful imitation of the «eastern imagination» of T.Moore by A.I.Podolinsky, Pushkin was at the same time repeatedly appealing to the images and motifs of «Lalla Rookh» in his works, giving them some original artistic interpretation. The image of Peri, included in Russian literature thanks to «Lalla Rookh» by Thomas Moore and the later poem «Div and Peri» by A.I.Podolinsky [see: 17, p. 82], was wide spread in the poetic everyday life of the edge of the $1820 \mathrm{~s}-1830$ s. It can be found in many poets' works (for example, V.A.Zhukovsky, M.Yu.Lermontov, A.I.Polezhaev, A.I.Odoevsky, A.S.Khomyakov) [18, p. 3-8], including Pushkin's poem «From Barry Cornwall» (1830), in a loose imitation of the song of B.Cornwall: «You can be more beautiful than Mary, / more beautiful than my Mary, / This little Peri; / But you cannot be any nicer / Than my frisky, affectionate Mary» [1, v. 2, p. 328].

In Pushkin's famous poem «To ***» («I just recall the wondrous instant... », 1825), dedicated to A.P.Kern, one can find the characteristic image of «a spirit of the pure grace»: «I just recall the wondrous instant: / You have arrived before my face, / A vision, fleeting in a distance, / A spirit of the pure grace» [1, v. 2, p. 89]. It is known that Pushkin was highly appreciating the A.A.Delvig's poem «To the album» («Oh, the power of wondrous beauty!... », 1823) [19, p. 101], that violated the anacreontic union of wine and love, traditionally sung by poets in the lyceum years: «Oh, the power of wondrous beauty! / To the love, experienced, cold / I forgot, free in my soul, / The dreams of my mad youth; / And I sang, dear to my friends, / About wine and friendship - you / You showed up, awaking my soul to torment, / And my lyre again started talking about love» [20, p. 155-156]. Lexemes, non-standardized word combinations used by Delvig («wondrous beauty», «you showed up»), later appeared in the lines of the Pushkin masterpiece. Both Delvig and Pushkin say that the true inspiration, escaped from the poet, comes back with a wondrous, pure beauty - the embodiment of poetry and love. Pushkin, who felt the euphony of some forms of art, presented by Delvig, managed to successfully include in his perfect work.

However, the image of «a spirit of the pure grace», appeared in Pushkin's poem, can hardly be attributed to the work of A.A.Delvig only. The poem «Lalla Rookh», created by V.A.Zhukovsky in Berlin between January 15 (27) and 7 (19) February, 1821, and dedicated to his Royal student - the Grand Duchess Alexandra Feodorovna, who participated in the part of Lalla Rookh in the Palace show [21, p. 102], contains the following lines: «Ah! It does not dwell with us / A spirit of the pure grace: / It only once descends / From heavenly heights to us» [22, p. 250]. The acquaintance of Pushkin with the poem of the predecessor poet is evidenced by the rewritten by Pushkin's hand reasonings of V.A.Zhukovsky about «Lalla Rookh» [14, p. 490-492]. In the drafts of the eighth chapter of «Eugene Onegin», one can find the stanza on a separate sheet, which was supposed to follow the XXX stanza, but not included in the final text, [16, p. 637]: «In a bright and rich hall, / In a silent and tight circle, / Like a winged lily, / Enters, embarrassed, Lalla-Rookh» [1, v. 4, p. 489]. Under the name of Lalla Rookh in Pushkin' verse the same august person of Alexandra Feodorovna is hided, who was at that time the Queen, the wife of the Russian Emperor Nicholas I. 
N.I.Chernyaev [23, p. 54] and A.I.Beletsky [24, p. 390-391] wrote that Pushkin borrowed the image of «a spirit of pure beauty» from «Lalla Rookh» by V.A.Zhukovsky, however, it is not as unambiguous as it may appear at first sight: this image can be found in other works of Zhukovsky - in a note «Madonna of Raphael» (1821): «... and she was there, where one can only be in the best moments of life. The spirit of pure beauty was with her» [25, p. 311] - in the verse «It happened that the young Muse ...» (1823): «Flowers of lonely dream / The best flowers of my life, - / I'm laying on your sacred altar / Oh, the spirit of pure beauty!» [22, p. 302]. I.P.Galyun points out the connection between the image of «a flying-by spirit», as a symbol of beauty in the works of V.A.Zhukovsky, and the works of F.Schelling, who was close to the Jena Romanticists (the poem «Lied») [26, c. 20-23].

Reflecting on the «spirit of pure beauty» in «Lalla Rookh», V.A.Zhukovsky emphasized the transience of being, the shortness of the moment of poetic inspiration, when the image of the highest beauty appeared before the creator. In a fit of creative inspiration, the poet breaks away from the perishable earth, from what is indisputable value to this world, from what is meaningful to him in real life, without feeling spiritual disharmony, for the lack of earthly communication is being compensated by the ability to free his spirit from the shackles of everyday life, to ponder over the eternal and tragic mysteries of being. In this way did Pushkin talk about the inspirational creator both in «The Poet» (1827) and in «Egyptian Nights», where he showed the transformation of man at the moment of «approaching of God», having created the image of an Italian improviser, - an extraordinary poet in moments of creativity, but an insignificant and greedy man in his daily life.

The prosaic introduction to the second part of the poem «Lalla Rookh» («Paradise and the Peri») in the edition of 1830 contains, among other things, the following description: «The caravan stopped at noon close to the spring, covered with branched bamboo, on which bark the well-known verse of Saadi was rough inscribed: "Many, like me, have visited this spring, but some are far away, while the eyes of others have closed forever". The melancholic beauty of this inscription gave Feramorz an opportunity to begin speaking about poetry» [27, p. 28]. The above inscription from the «Garden» of Saadi, written by someone's rough hand near the spring, firmly imprinted in the memory of Alexander Pushkin, who used it in the following texts: the poem «The Fountain of Bakhchisarai» (1824), the notes «Objections to the critics of «Poltava» (1830), LI strophes of the eighth chapter of «Eugene Onegin» (1829-1830) (verses «Some dwell no more, but some are far away, / As Saadi once said» [1, v. 4, p. 178]), a draft of the poem «All is quiet, the Caucasus is covered with a night haze» (verse «Some are far away, there are no others in the world») [28, p. $110-111 ; 29$, p. 383-384; 30, p. 506; 31, p. 133-134]). When revealing the story of «The Fountain of Bakhchisarai» creation, the text of which was preceded with an epigraph from Saadi. «Many, like me, have visited this fountain, but some dwell no more, others travel far away» [1, v. 3, p. 143], Pushkin in his «Objections to the critics of «Poltava», published in the Almanac «Dennitsa» in 1831, wrote that as a manuscript «The Fountain of Bakhchisarai» was called «Haron», but «a melancholic epigraph (which, of course, is better than the entire poem) seduced me» [1, v. 6, p. 76] to change the title. Bearing in mind the Russian poet's attitude to «Lalla Rookh» by Moore, one can, following M.P.Alekseev [32, p. 691], confidently say that Pushkin puts Saadi's words, cited by an English romantic, above his eastern poem in general. There is one more point of convergence between «Lalla Rookh» by T.Moore and Pushkin's creativity, that is, the proximity of the death of the heroes from plague in a poem by T.Moore and the description of «Feast in Time of Plague» in the «little tragedy» by a great Russian poet. Pushkin is known to make up the plan under the influence of the three-act dramatic poem «The City of the Plague» by J. Wilson, depicting the London Plague of 1666 [33, p. 113-114]. The influence of Moore is traced in describing the farewell of the beloved, dying of the plague, with another one, staying alone: "When the early grave / Is destined to my spring - / You, whom I love so much / / Whose love is my joy, - / I beg: do not approach / Your Jenny's body; / Do not touch the dead lips, / Follow her from afar» [1, v. 4, p. 375]. There is no such description in Wilson, but it is found in «Lalla Rookh» by Moore: «Then turn to me, my own love, turn / Before like thee I fade and burn. / Cling to these yet cool lips and share / The last pure life that lingers there!» [34, p. 137]. As you can see, the maid in Moore's poem tragically looks at the future parting with her dying lover; she craves death, and consequently asks the dying boy to cling to her lips. Pushkin, being far from the tragedy of Moore, introduces a hedonistic motive into the description of the feast: «So, we praise you, Plague, / The grave of darkness will not frighten us, / $<\ldots>/$ We are all together foaming glasses / And drinking the breath of a rose-maiden - / Maybe ... full of Plague» [1, v. 4, p. 378-379]. 
The comparison of the maiden and the rose, found in the above Pushkin fragment, became stable largely due to the work of K.N. Batyushkov, who wrote in the «Imitation of Ariosto» (1821): «The young girl is like a tender rose, / Cherished in spring under a secure shadow» [35, p. 182]. In earlier works of Batyushkov, which had a significant impact on Russian literature, that comparison was not less vivid: in Batyushkov's imitation of G.-B.Casti «Joy» (1810), a beautiful girl resembled a rose «with a head, heavy with / priceless drops» [35, p. 125] (this comparison is not available in Casti), and in «Tavrida», written in 1815, the woman was «ruddy and fresh like a wild rose» [35, p. 57]. Without attributing the authorship of the expressive comparison of the rose and the captivating beauty to Batyushkov (it was first encountered in the sonnet «Do not waste, beauty, your time in vain...» by A.P.Sumarokov), however, one cannot but admit that it was his romantic interpretation, included in the works of Pushkin, A.A.Delvig («Rose», 1822 or 1823, [36, p. 115]), P.A.Katenin («Octaves from the "Mad Roland" (From Ariosto)», 1822, 37, p. 128]), N.M.Yazykov («To A.A.Elagin», $1841 ;[38$, p. 371]) and so on.

The quotation from the fourth part of «Lalla Rookh» («The Light of the Harem») in the original language is included by Pushkin in the description of Teflis' brooks at the beginning of the second chapter of «Traveling to Arzrum during the campaign of 1829» (1835): «At the entrance of the baths there sat the owner, the old Persian. He opened the door for me, I went into the vast room and what did I see? More than fifty women, young and old, half-dressed and not dressed at all, were undressing, while sitting and standing, and dressing on benches, placed near the walls. Many of them were really beautiful, justifying the imagination of T. Moore: "a lovely Georgian maid, / With all the bloom, the freshen'd glow / Of her own country maiden's looks, / When warm they rise, from Teflis' brooks. Lalla Rookh”» [1, v. 5, p. 429-430].

In a note Pushkin gave the following prosaic translation of the quoted verse passage: «A charming Georgian maiden with a bright blush and fresh glow that is inherent in the faces of the maidens of her country, when they come out hot from Teflis' brooks» [1, v. 5, p. 430]. We can assume that, despite the presence in the poet's library of the Parisian one-volume book of 1829, containing «Lalla Rookh» in English [15], Pushkin got the idea of Teflis' brooks and charming Georgian women from another, indirect source, first of all, from the prosaic translation of «The Light of the Harem», anonymously published in 1827 in No. 5 of «The Son of the Fatherland». M.P.Alekseev believes that Pushkin could have taken the quotation from «Lalla Rookh» from the review of three new works on the Caucasus [32, p. 701], published by the «Edinburgh Review» (Edinburgh Review. - 1817. - V. XXVIII. - P. 302-335). Indeed, the review of the book «Lettres sur le Caucase et la Géorgie, suivies d'une relation d'un voyage en Perse en 1812» (Hambourg, 1816) contains the notes about Teflis' brooks, Georgian girls and the familiar to us quotation from «Lalla Rookh».

As we can see, there are a lot of allusions from «Lalla Rookh, an oriental romance» by T.Moore in Pushkin's works. It is obvious that these allusions have prompted many contemporaries of the two poets to seek analogies in their work. Even N.V.Stankevich, who compared the emotional poetry of Moore with the lyrics of Goethe and Pushkin in his letter to T.N.Granovsky dd. August 27-30, 1837, did not escape it: «He's got such a solid feeling, which is sad, true, Russian and daring at the same time. Goethe has got the similar poems too. As far as I know Moore has especially many; only Pushkin is less fantastic, more Fleisch und Blut: the feeling here is undeveloped and simple» [39, c. 472]. However, neither the examining of the specific allusions of «Lalla Rookh» by Moore in Pushkin's works, nor the perception of the ways of influence of the English predecessor on the Russian genius, allows us to draw a conclusion about the inner kinship and spiritual affinity of the two poets.

In 1824, shortly after Byron's death, three notes appeared in the «Son of the Fatherland», the first of which was informing of the intention of Thomas Moore to publish the autobiographical notes of Byron, sent to him [40, p. 40-41]; the second - about T.Moore who burned Byron's manuscript, after receiving his sister's letter, who «found many places in it, offensive to those who are still alive», and returned the money, he «received for permission of printing the manuscript», to the bookseller [41, p. 95]; finally, the third note said that «the public has not lost the notes of Lord Byron, for there are copies of them» [42, p. 188]. A considerable part of Russian society was indignant with Moore who, according to V.F.Odoevsky, «considered it a duty of wellbeing to despise the will of a friend, and give his memory to mockery, so as not to offend a couple of bonnets» [43, p. 154; see also: 44, p. 31]. Even after some time, in the translated article «Lord Byron and Some of His Contemporaries» by Lee Hunt, published with a continuation in No. 14-15 of the «Literary 
Gazette», dd. 1830, Moore was condemned by the public for «harm that he may have without intention, caused his noble friend» [45, c. 110].

Pushkin's position, reflected in the pages of the periodical press, was contrary to the opinion that prevailed in Russian society. Pushkin, puzzled by the general outrage of Moore's act, explained his point of view in a letter to P.Vyazemsky, dated late November 1825: «Why do you regret losing Byron's notes? To hell with them! Thanks God they are lost. In a cold-blooded prose he would have lied and sneaked, once trying to shine with sincerity, and then painting his enemies with black. He would have been caught, like they caught Rousseau - and anger and slander would again triumph. Leave the curiosity to the crowd and stay in concert with the genius» [1, v. 9, p. 215]. As we see, there could not be greater revelation in Pushkin's consciousness than that contained in verses as the most complete expression of the spiritual world of the poet.

The further perception of Thomas Moore as a biographer of Byron, the author of a unique work that lifted the veil over the vague circumstances of the life of the English romantic, showing his human features, rather than as an original poet, was largely stipulated by the book «Letters and Journals of Lord Byron with Notices of His Life», prepared by Moore and published in London in 1830 [46, p. 61]. Russian censors considered it undesirable to distribute the book about Byron in Russia, but it nevertheless penetrated readers [see: 47, p. 134, 244] and aroused great interest of Pushkin [48, p. 110-111; 6, p. 806] and his educated contemporaries. The French translation of the book by Thomas Moore, carried out by Louise Sw.Belloc [49] and published in separate editions beginning from 1830, got fame among Russian readers.

M.P.Alekseev found in the Institute of Russian Literature a number of A.I. Turgenev's documents, which allowed to speak about the significant interest that Thomas Moore showed to Russian literature and, in particular, to Pushkin's works. In the diary of A.I.Turgenev, the researcher discovered two noteworthy entries, relating to 1829: «Feb. 20. I met Th.Moore in Athenaeum who asked to give a note about the translators of Byron in Russia. I wrote about Zhukovsky, Pushkin, Kozlov, Vyazemsky.

21 February. I gave him a note in Athenaeum, where we agreed to meet. He has already told the publisher Murray about my copy of biography of Byron (Albemarle Street), and I gave him the works of Kozlov ...» [50, No. 308, sheet 38; 51, p. 252].

The mentioned note is also preserved in the papers of A.I.Turgenev; M.P.Alekseyev gives its full French original, accompanied by a Russian translation. A.I.Turgenev made the following judgment about Pushkin as a Russian follower of Byron: «Poushkine, qui s'est formé sur Byron et don't le génie s'est essayé dans presque tous les genres de poésie parmi lesquels il y a des chefs-d'oeuvres, l'a imité dans "La mer", dans son "Napoléon" et dans d'autres pieces qui vivpont aussi longtemps qu'on parlera notre langue» («Pushkin, formed on Byron, who used his talent in almost all genres of poetry - among them there are masterpieces imitated him in «To the Sea», in his «Napoleon» and in other works, that will live as long, as live our language speakers») [50, No. 367; 51, p. 255, 257]. Turgenev further quoted Pushkin's lines, translated by him into French and by V.P.Davydov into English.

Moore probably planned to include some information about the Russian translators of Byron in a book, prepared for publication, about his great compatriot and friend, but failed. When continuing his search, M.P.Alekseev found in the diary of A.I.Turgenev the following entry, dated April 2, 1829: «Wrote to Thomas Moore at Sloperton Cottage, Devizes and sent translations of Dave and Cramer, Pushkin about Napoleon and Byron» [50, No. 308, sheet 32; 51, p. 264]. The researcher also found in the archive a rough copy of the letter of A.I.Turgenev to Thomas Moore, dated April 2, 1829, later published in French and translated into Russian [51, p. 268-270]. In his letter, A.I.Turgenev described Pushkin as he «who ran through each mode of the lyre and was master of all», literally quoting the 9th verse of Moore's poem «Lines on the Death of Sheridan» (1816).

\section{CONCLUSIONS}

As we see, despite negative judgments about Moore and rejection of his «Lalla Rookh, an oriental romance», Pushkin in no way belittled the role of the English poet in the development of world literature. He often called his name along with the names of recognized foreign classics and tried to be in the course of Moore's 
new works, carefully reading and collecting them, including the rarest, in his library. Thomas Moore also knew Pushkin, having received a fairly complete idea of his «Byronism» from the letters of A.I.Turgenev. However, the material, reported by A.I.Turgenev, was only taken into account by Moore, but was in no way used either in his book, «Letters and Journals of Lord Byron with Notices of His Life», or in subsequent works.

\section{ACKNOWLEDGEMENTS}

The article has been prepared within the project No. 34.5063.2017/BCh "Russian Reception of Dramaturgic Art of Shakespeare's Contemporaries (Problems of Textual Criticism and Poetics)" of the state task to the higher education institution of the Ministry of Education and Science of the Russian Federation.

\section{REFERENCES}

1. Pushkin, A.S. Collected Works: In 10 vols. - Moscow: State Institute of Fiction, 1959-1962. - V. 1-10.

2. Modzalevsky, B.L. Library of A. S. Pushkin. - St.Petersburg: Printing House of Petersburg Academy of Sciences, 1910. -442 p.

3. Lalla Roukh ou la Princesse Mogole. Histoire orientale par Thomas Moore, par le traducteur des oeuvres de Lord Byron. - Pontieu, 1820. - 2 vols.

4. Bisson, L.A. Amedée Pichot. A Romantic Prometheus. - Oxford: B.Blackwell, 1942. - XV, 422 p.

5. Delvig, A.A. Compositions. - Leningrad: Fiction (Leningrad branch), 1986. - 472 p.

6. Literary heritage. V. $16-18$. A.S. Pushkin / Ed. by I.S.Silberstein and I.V.Sergievsky; reprinted edition. Moscow: The Institute of World Literature of the Russian Academy of Sciences, 1999. - 1183 p.

7. Shevyrev, S.P. «Manfred», composition of Lord Byron // The Moscow Herald. - 1828. - Ch. 10. - P. 5169.

8. Gaevsky, V.P. Materials for the biography of Alexander Pushkin: [review. On the book by P.V. Annenkov «Materials for the biography of Alexander Pushkin»] // Otechestvennye zapiski. - 1855. - V. 100. - No.6. Dep. III. - P. 31-70.

9. Yakovlev, N.V. The last literary interlocutor of Pushkin // Pushkin and his contemporaries. - Petrograd: Publishing House of Petersburg Academy of Sciences, 1917. - Issue. XXVIII. - P. 5-28.

10. Yakovlev, N.V. From searches about literary sources in Pushkin's work // Pushkin in world literature. Leningrad: The State Publishers, 1926. - P. 113-159.

11. Modzalevsky, B.L. A trip to the village of Trigorskoye in 1902. Appendix I: Catalog of the library of the village of Trigorskoye // Pushkin and his contemporaries. - St. Petersburg, 1903. - Issue. I. - P. 1-190.

12. Maltseva, T.M. Pushkin - as a reader of the Trigorskoye library // Pushkin's collection. - Pskov: Pskov State Pedagogical Institute named after S.M.Kirov, 1962. - P. 32-43.

13. Institute of Russian Literature of the Russian Academy of Sciences. - Fund 244. - Inventory 1. - Case 211.

14. By the hand of Pushkin. Not collected and unpublished texts / Edition prepared by M.A.Tsyavlovsky, L.B.Modzalevsky, T.G.Zenger. - Moscow: Academia, 1935. - 926 p.

15. The Poetical Works of Thomas Moore, Including His Melodies, Ballads, etc. Complete in one volume. Paris: A. and W. Galignani, 1829. - 409 p.

16. Pushkin, A.S. Complete works: In 19 vol. - Moscow: Sunday, 1999. - T. 6. - 792 p.

17. Semevsky, M.I. Andrei Ivanovich Podolinsky, a collection of his unreleased poems. 1830-1884 // Russian Antiquity. - 1885. - No.1. - P. 73-118.

18. Zhatkin, D.N, Dolgov, A.P. Peri in Russian poetry// Russian speech. - 2007. - No.3. - P. 3-8.

19. Zhatkin, D.N. A. Delvig's poetry and historical and literary traditions. - Moscow: «Taganka»Publishing House, 2005. - $268 \mathrm{p}$.

20. Delvig, A.A. Complete collection of poems. - Leningrad: Soviet writer, 1959. - 369 p.

21. The diaries of V.A. Zhukovsky / Note of I.A. Bychkova. - S.Petersburg: Publishing House of Partnerships «Public benefit», 1903. - 536 p.

22. Zhukovsky, V.A. Poems. - Leningrad: Soviet writer, 1956. -848 p.

23. Chernyaev, N.I. Epistle «To A.P. Kern» by Pushkin and «Lalla Rookh» by Zhukovsky // Chernyaev, N.I. Critical articles and notes on Pushkin. - Kharkov: Publishing House of the Kharkov University, 1900. - P. $33-64$.

24. Beletsky A.I. Selected works on the theory of literature. - Moscow: Education, 1964. - 482 p.

25. Zhukovsky, V.A. Aesthetics and criticism. - Moscow: Sovremennik, 1985. - 431 p.

Submit Date: 12.02. 2018, Acceptance Date: 27.02.2018, DOI NO: 10.7456/1080MSE/115

Research Article - This article was checked by Turnitin

Copyright (C) The Turkish Online Journal of Design, Art and Communication 
26. Galyun, I.P. On the literary influences in the poetry of V.A. Zhukovsky. - Kiev: Publ.House of The Imperial University of St. Vladimir, 1916. - [2], $31 \mathrm{p}$.

27. Moore, T. Lalla Rookh: An Oriental Romance. - Moscow.: Publ.House of August Semyon under the Imperial Medical-Surgical Academy, 1830. -88 .

28. Lerner, N.O. Pushkinological studies // Links. - Moscow; Leningrad: Academia, 1935. - T. V. - C. 44187.

29. Vinogradov, V.V. Pushkin's style. - Moscow: The State Publishers, 1941. - 620 p.

30. Tomashevsky, B.V. Pushkin. - Moscow.; Leningrad.: Publishing House of the Academy of Sciences of the USSR, 1956. - Book. 1. - 744 p.

31. Nolman, M.A. Pushkin and Saadi (on the interpretation of the poem «In the cool of the sweet fountains» / / Russian literature. - 1956. - No. 1. - P. 123-134.

32. Alekseev, M.P. Russian-English literary connections (XVIII century - the early XIX century). - Moscow: Nauka (Science), 1982. - 864 p.

33. Yakovlev, N.V. On the sources of the «Feast in Time of Plague» (Materials and observations) // Pushkin's collection in memory of S.A. Vengerov. - Moscow; Petrograd: The State Publishers, 1923. - P. 93-170.

34. Moore, T. The poetical works. - L.; N. Y.: Edward Arnold \& Co, 1910. - 540 p.

35. Batiushkov, K.N. Poems. - Moscow: Fiction, 1988. - 320 p.

36. Delvig, A.A., Kukhelbecker, V.K. Favorites. - Moscow: Pravda (Truth), 1987. - 640 p.

37. Katenin, P.A. Selected works. - Moscow; Leningrad: Soviet writer, 1965. - 744 p.

38. Yazykov, N.M. Complete collection of poems. - Moscow; Leningrad: Soviet writer, 1964. - 706 p.

39. Stankevich, N.V. Correspondence. - Moscow: V. Kirschbaum Publishing House, 1914. - IX, 787 p.

40. <Anonymous note from the «Chronicle»> // Son of the Fatherland. - 1824. - No. XXI. - P. 40-41.

41. <Anonymous note from the «Chronicle»> // Son of the Fatherland. - 1824. - No. XXII. - P. 95.

42. <Anonymous note from the «Chronicle»> // Son of the Fatherland. - 1824. - No. XXIV. - P. 188.

43. The Russian National Library. - Fund 539. - Inventory. 1. - No. 26. - Sheet 154.

44. Odoevsky, V.F. Russian nights. - Leningrad: Nauka (Science), 1975. - 316 p.

45. Hunt, L. Lord Byron and some of his contemporaries // Literaturnaya gazeta (Literary Gazette). - 1830. - No. 14. - P. 110-113; No. 15. - P. 123-124.

46. Maslov, V.I. The initial period of Byronism in Russia. - Kiev: Publishing House of the Kiev Commercial Institute, 1915. - $132 \mathrm{p}$.

47. «Literary Gazette» of A.S. Pushkin and A.A. Delwig. 1830 (No. 1-13) / Comp. by V.N. Anoshkina, T.K. Baturova. - Moscow: Contemporary, 1988. - 256 p.

48. Kozmin, N.K. Pushkin on Byron // Pushkin in World Literature. - Leningrad: Publishing House of the USSR Academy of Sciences, 1926. - P. 99-111.

49. Memoires de Lord Byron, publies par Th. Moore, traduits de l'anglais par M-me Louise Sw.Belloc. Paris: Alexandre Mesnier, 1830. - 448 p.

50. Institute of Russian Literature of the Russian Academy of Sciences. - Fund 309. - No.308, 367.

51. Alekseev, M.P. Thomas Moore, his Russian interlocutors and correspondents // International Relations of Russian Literature. - Moscow; Leningrad: Science, 1963. - P. 233-285. 